\title{
Natural resources as a value important to the development of ecological consciousness of the polish society
}

\section{Zasoby przyrody jako wartość ważna w rozwoju świadomości ekologicznej społeczeństwa polskiego}

*Dr hab. Ilona Żeber-Dzikowska, prof. nadzw. - Institute of Humanities and Social Sciences, The State School of Higher Professional Education in Płock, Gałczyńskiego 28 St., 09-400 Płock; Institute of Biology, the Jan Kochanowski University in Kielce, Świetokrzyska 15 St., 25-406 Kielce; e-mail: ilona.zeber-dzikowska@ujk.edu.pl

**Dr Jarosław Chmielewski - Institute of Environmental Protection-National Research Institute, Krucza 5/11d St., 00-548 Warsaw.
***Drhab. Stanisław Lachowski - Institute of Rural Medicine, Jaczewskiego St., 20-090 Lublin, Maria Curie Skłodowska University in Lublin, Marii Curie-Skłodowskiej 5 Sq., 20-031 Lublin.

Keywords: natural resources, ecological consciousness, value, development, Polish society, pro-ecological attitudes, eco-philosophy, sustainable development

Słowa kluczowe: zasoby przyrody, świadomość ekologiczna, wartość, rozwój, społeczeństwo polskie, zachowania proekologiczne, ekofilozofia, zrównoważony rozwój

\section{Abstract}

The authors examine a very important issue concerning the concept of public consciousness and ecological consciousness of a human. They present ecological consciousness through indicating its level and factors that determine it. They discuss questions connected to shaping ecological consciousness in teachings of Saint John Paul II, sustainable development, ecophilosophy, and pro-ecological attitudes.

(c) IOŚ-PIB

\section{INTRODUCTION}

Nowadays, the natural environment is seriously threatened by human destructive activities. The constant development of industry results in negative consequences for the environment. High level of air pollution or increasing amount of waste is one of the many threats to the environment.

It is crucial to raise public ecological consciousness understood as conscious respect for the natural world and the feeling of involvement and direct relation with the nature. It is people who have the major influence on the surrounding world, and for that reason, everybody must be aware of the consequences that result from neglecting the nature.

The content of the article primarily depicts what ecological consciousness consists and outlines the attitude of Saint John Paul II towards the nature. He used to urge people to respect the nature, use natural resources reasonably, and not forget the value of life and well-being of other humans. Also, he emphasised the importance of respecting the nature with well-being of the other human in sustainable development as its fundamental aspect. In its further part, the article elaborates on the definition of ecophilosophy and forms of pro-ecological attitudes connected with waste management and air pollution.

\section{THE CONCEPT OF CONSCIOUSNESS}

The term 'consciousness' originates from the Latin word conscientica, which means 'conscience'. Christian Wolff was

\section{Streszczenie}

Autorzy podejmują bardzo ważny problem dotyczący pojęcia świadomości ogólnej oraz świadomości ekologicznej człowieka. Ukazują świadomość ekologiczną poprzez zarysowanie jej poziomu i czynników ją warunkujących. Przybliżają zagadnienia związane z kształtowaniem świadomości ekologicznej w naukach Św. Jana Pawła II, zrównoważonym rozwojem, ekofilozofią, zachowaniami proekologicznymi.

the first to introduce the term, but the first Greek philosophers, including Aristotle, found human senses intriguing. According to them, the sense that is now called consciousness is responsible for embracing actions of all the senses. Since the dawn of time, many people have been keen to know how the human brain functions. Aristotle, St Thomas Aquinas, John Locke, Descartes, or Nagel are among those who regarded the brain to be something special and exceptional. According to Locke, with time, the mind gains new experience and ideas that are formed in response to external stimuli and sensations.

Introspection is a method that gives us a chance to become familiar with internal states of consciousness. It derives from Latin words spicere and intra, which mean, respectively, see and inside. It is dependent on, subordinated to it, higher-order mental states from the level on which it is conducted. Despite extensive research and numerous opinions that have been formed about the functioning of human consciousness since antiquity, it has not been thoroughly examined yet [Drobot 2012].

\section{ECOLOGICAL CONSCIOUSNESS OF PEOPLE}

Ecological consciousness is, undoubtedly, a term that bears a number of meanings. It can be understood as general knowledge of the natural environment or as a set of laws, judgments, and views concerning the environment as the area for a human's 
proper growth. However, scientists refer to ecological consciousness not as to a sociology term, but exclusively a set of beliefs held within a particular period of time and on a specified area introduced by a team of researchers in order to protect public welfare and surrounding nature.

Ecological consciousness is not merely, as it might appear, an element of knowledge concerning environmental values, but also ethical ones. These views could support a belief that every creature living on the Earth is granted the right to live [Papuziński 2006].

The major factor in raising public ecological consciousness is the influence on the way people think and on behaviour connected with their surroundings. Undoubtedly, what is also important is politics of a country, which, through promoting habits of the positive influence of a society on the nature, subsidises various projects, encourages its citizens with prospects for health improvement that results from ecology, and introduces school lessons that aim at sharing all these values with children. Raising ecological consciousness can undergo four stages: becoming conscious, becoming interested, a will, an action (Fig.1).

Research conducted on Polish people reveals that a substantial majority of citizens of our country do not demonstrate sufficient knowledge of the natural environment and do not pay any attention to its protection believing that it is the local authorities who are responsible for all pro-ecological activities [Tuszyńska 2008; Drobot 2012;]. Other research findings, conducted on a group of students, also prove a low level of ecological consciousness [Tuszyńska 2006; Wójtowicz 2010a, 2010b; Wójtowicz, ŻeberDzikowska 2006, 2011].

Environmental prosperity is important for merely half of the interviewees [Bednarek-Gejo et al 2012].

\section{ECOLOGICAL CONSCIOUSNESS - LEVEL AND FACTORS DETERMINING IT}

The level of ecological consciousness is dependent on the knowledge that an individual possesses in this subject and also emotions that accompany it; hence, it can be put on three levels: high, medium, and low.

High level indicates a human's deep relation with the surrounding nature. Such people are at risk of suffering from psychological stress when a threat of environmental disturbances occurs in their surroundings. On the medium level, people's ecological consciousness is high, but their behaviour does not go beyond the limits of common sense. By contrast, people who are placed on low level are aware of the threats to the ecosystem, but it is not enough to influence their attitudes to the surrounding world. Unfortunately, in the Polish society, the last of the described levels prevails.

The crucial factors affecting the development of people's ecological consciousness are undoubtedly the opportunity to draw a variety of benefits from it: health benefits, financial benefits, or feeling of security as well as religious and ethical values. Two major factors are certainly health, and what follows, security [Klimczyk-Bryk 2000]. Other factors are presented in figure 2.

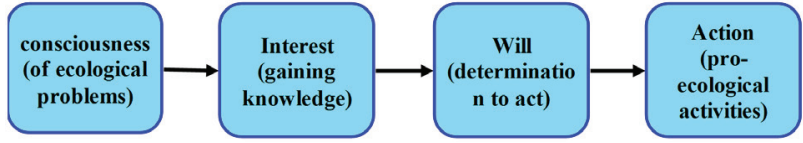

Figure 1. A simplified process of transition from ecological consciousness to action [Klimczyk-Bryk 2000].

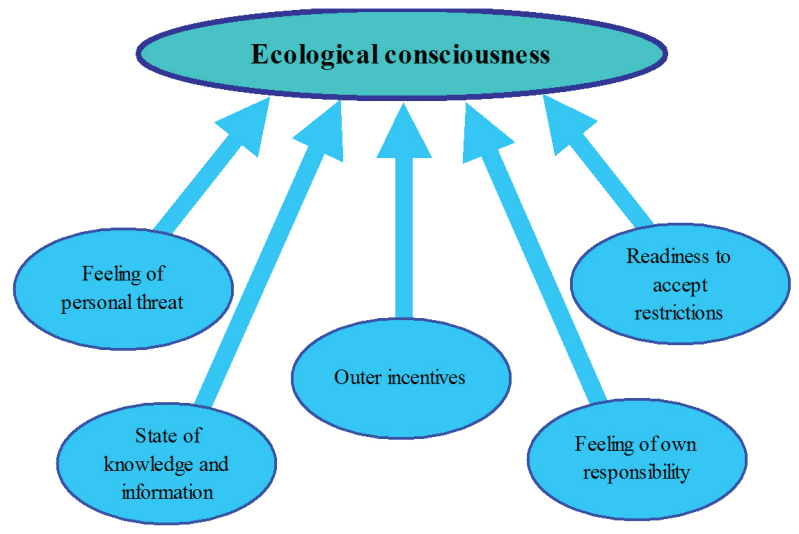

Figure 2. Factors determining the consumers' ecological consciousness [Klimczyk-Bryk 2000].

\section{RAISING ECOLOGICAL CONSCIOUSNESS FROM THE TEACHINGS OF SAINT JOHN PAUL II}

The environment is not only beautiful landscapes that surround us or home for animals living in the wild. Far and foremost, it is the surroundings vital in every human's life. It is the environment that provides a human with food and resources necessary for the development of an individual organism as well as the whole community. Some of the ecosystems we live in undergo constant degradation due to all human activities, such as, for example, industrial development. It is the human who adversely affects his own development through his negative influence on the surrounding world [Bełch 2010].

In his encyclicals and proclamations, Saint John Paul II repeatedly emphasises the significance of the nature. In his speech for scientists on $5^{\text {th }}$ September, 1993 , he says, "Mankind is still being humiliated by violence and all kinds of intolerance, afflicted with hunger and poverty of millions, threatened by an ecological crisis on such a massive scale that it evokes fear of "environmental destruction», not the least distressing than a threat of nuclear destruction". In 2000, in his proclamation, John Paul II encourages us "to become aware of the responsibility all people bear for the natural environment and for situations of poverty and exploitation in which vast numbers of people worldwide live". Also, in his other numerous speeches, John Paul II mentions the issue of the natural environment, among others, in the speech delivered to the participants of the conference 'Man and the environment' in 1990, in the speech to the members of the Pontifical Academy of Sciences in 1999 or in his homily during the liturgy in Zamość in 1999. He says that each individual is obliged to act reasonably for the sake of the environment since disrespecting the laws of nature and restrictions imposed on the value of life can drive mankind to destruction. The nature is not an exclusive possession of an individual, but was created by 
God as common good for all people. However, contrary to the popular belief, it is the behaviour of individuals that has the major influence on the surrounding world.

In 2001, John Paul II unambiguously emphasises human adverse activities aimed at the nature saying, "Unfortunately, when we have a closer look at different regions of our planet, we will realize that mankind have not met God expectations. Particularly nowadays when a man has carelessly devastated forest valleys and hills, contaminated water, damaged global environment, polluted the air, disrupted hydrogeological and atmospheric systems, turned fertile lands into deserts, lost control over the development of industry, trampling disdainfully". Further in the same speech, the Pope mentions the importance of a human's responsible actions towards the surrounding world and encourages people to base environmental protection not only on selfish behaviour minding their own prosperity, but to feel concerned about the good and love of their neighbours, to rule the surrounding world wisely the way it has been intended since the Creation of the World. Furthermore, John Paul II and Patriarch Bartholomew I [2002] speak about the general responsibility to raise ecological consciousness as an aspect vital to shape public attitudes. Higher ecological consciousness of a man is supposed to bring him closer to the Creator and to strengthen the bond between God and people. They also call for respect for life, claiming that every creature, without exception, has the right to live. "Respect for all creation results from respect for human life and human dignity. Acknowledging that the world is created by God allows us to recognise the objective moral order, within which the code of ethics of the natural environment can be formulated. From this perspective, Christians and other believers should perform a vital role in sharing moral values giving upbringing in ecological consciousness, which is nothing else but responsibility towards themselves, towards others and towards creation." According to them, omnipresent arrogance is the most acute problem of a contemporary man concerning a lack of ecological consciousness and his unwillingness to protect the environment adequately. It covers true values and stops people from taking rational decisions on the environmental protection, and in consequence, life. To their mind, only humble people are able to spot the increasing problem and rebuild the degraded surroundings in a rational way, thus restoring harmony.

Unfortunately, as the Servant of God John Paul II declares [1979], a man has been 'an exploiter'. He takes advantage of the natural resources in an irresponsible and unreasonable way, thus producing negative effects, such as: the greenhouse effect and the ozone hole or increasingly common disasters: floods, hurricanes, and so on. That proves the unity between the people and nature has been shattered. These days, a man is becoming fascinated by technology, which is the major reason for his detachment from the nature. Modern lifestyle encourages a change in mentality, morality, and even the structure of society. The conviction that prevails in such mentality attaches greater importance to products developed by people than the act of creation since technology is considered something more valuable than the nature. Sensitivity to its aesthetic, psychological, religious, economic, and biological values are eclipsed. All devices beneficial for human development also determine his deeper attachment to comfort, and in consequence, a human becomes a slave to these devices. We tend to forget that it is hardship and suffering that put value to human life and enrich it. John Paul II [1991] indicates that the path followed at the moment focussed principally on the protection of endangered species, and neglecting human moral values leads to nowhere. We cannot forget it is the other human who is most important in the surrounding world, and it is his welfare that should be identified as the priority for each of us, not animals or plants, although they are also important to maintain the ecological balance, but to a lesser extent than a man. The Pope emphasises that it is family that is the most important. It is the basic entity building the human ecology. Its value must be defended above all, especially these days when there are so many attacks against traditional family. The Pope [2001] claims that "nowadays, distortional and highly dangerous views are being spread and they are fed by relativistic ideology circulated in all environments by the media. In fact, however, the burning issue concerning the welfare of the state and society is the protection of a family based on marriage understood as a public act approving and regulating mutual commitments, as taking total responsibility for the other person and children, and also as a relationship involving rights and duties, and as the fundamental unit of society on which life of a nation relies". He also adds that "family, as an institution capable of enabling an individual to acquire a sense of identity in the right way, provides him, at the same time, with the environment corresponding with natural dignity and vocation of a man".

It is the man who is responsible for the surrounding world and living conditions. John Paul II [1999] admits that all people, regardless of their religion, should follow these values. Also, referring to the Creation of the World by God, the Pope [1995] mentions that a human should not regard himself as equal to the master of all creation. He states, "when confronting with the visible nature, we are subject not only to laws of biology but also to moral ones that cannot be broken with impunity".

The Pope repeatedly emphasises the significance of the harmony of a human and the natural environment. He says that it is vital that people should manage the world created by God in an intelligent way, so that they can find Almighty and Immanent Creator in the nature. It is essential that all actions should not affect adversely the other human and should not destroy his dignity and deny him the right to live [Jaromin 2012]. The right applies to everyone with no exception from their conception to natural death. The Pope repeatedly stresses the importance of human life as the biggest good of a man. He says that no man has the right to raise his hand against another man, even an unborn one. Life in every form must always be protected. The question of abortion is often the subject of debate, but no one has asked the unborn children about their opinions. John Paul II [1979] states, "if a man is denied the right to live at the moment of his conception under his mother's heart, moral order that serves to secure inviolable human goods is threatened. Life is the prime of these goods".

\section{SUSTAINABLE DEVELOPMENT}

The concept gained popularity in 1987, thanks to the World Commission on Environment and Development (United 
Nations). Sustainable development refers to the constant technological advancement. It is "the process aimed at meeting aspirations towards development of the present generation that, simultaneously, provides future generations with the opportunity to achieve the same aspirations" [Gawor 2006].

The findings of research conducted in Poland in 2008 and 2009 revealed that the concept of sustainable development of the natural environment is not completely familiar to the society. Only $33 \%$ of the respondents were able to give the precise definition, whereas as many as $70 \%$ of them stated that the environment free of pollution is a true value to them [Bołtromiuk 2010].

Undoubtedly, the significant factor in sustainable development is shaping the pro-ecological attitudes of society through education. It is advisable to shape behaviours connected with the environmental protection among people from all social backgrounds and inform them of the dangers that the polluted environment poses [Hłobił 2010].

Also, the churches frequently express their viewpoint on sustainable development in the context of the good expressed to the other human. They remind that "the agreement in aid of sustainable development must recognise and preserve human rights and dignity. The Holy See feels responsible to remind that in discussions about sustainable development most attention should be paid to the human being" [Martino 2002].

\section{ECO-PHILOSOPHY}

The word philosophy originates from the Greek words phileo and sophia, which mean, respectively, "love" and "wisdom". Generally speaking, it is a common study of the world. The term bears three basic definitions shown in figure 3 .

Eco-philosophy is the term of a similar origin to the previous one, but it consists of three Greek words. Apart from phileo and sophia, it also includes the word oikos that means 'environment'. So, "eco-philosophy is a philosophical study of the natural and social environment that is of the ecosystem of the Earth and its surroundings with theoretical and practical aspects" [Dołęga 2006]. Generally speaking, it makes up a set of projects concerning the environmental protection. A further concept of academic philosophy applies to the ideology of maintaining harmony between a human and the environment [Hull 2006].

The philosophy has resulted from the considerably increasing degradation of the natural environment. It aims at confronting the public with the problem and promote the right attitude towards the nature. The beginnings of its dynamic development dates back to 1960s in USA. In Poland, the concept of eco-philosophy arouse at the turn of 1980s. The issue of the development of ecological consciousness and environmental ethics originated due to a rising number of articles and books being published at the time [Tyburski 2006]

\section{PRO-ECOLOGICAL BEHAVIOUR}

Education in the area of pro-ecological behaviour of society is vital to maintain the balance between the environment and health. One of the modern problems is vast and still increasing amount of waste. Therefore, the United Nations (UN) authorities introduce a

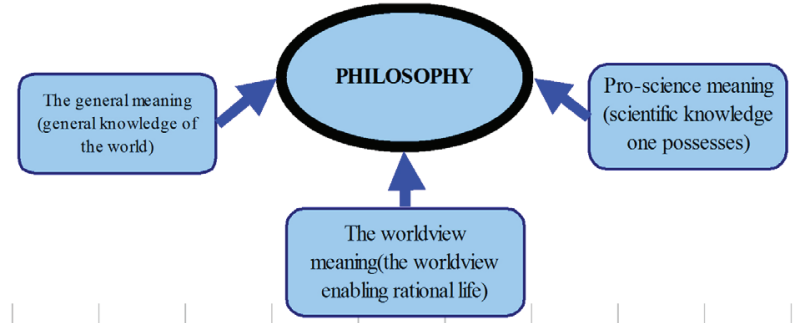

Figure 3. General shades of meanings of the term of philosophy

Table 1. Positive and negative aspects of processing primary energy carriers into final energy [Lorenz 2005].

\begin{tabular}{|c|c|c|}
\hline & Positive sides & Negative sides \\
\hline Coal & $\begin{array}{c}\text { Abundance of supplies, } \\
\text { certainty, security } \\
\text { Easy to transport and } \\
\text { store } \\
\text { Widely available }\end{array}$ & $\begin{array}{l}\text { The most carbon-rich } \\
\text { fuel used to produce } \\
\text { electrical energy } \\
\text { Poses challenges to } \\
\text { reduce } \mathrm{CO}_{2} \text { emission }\end{array}$ \\
\hline Oil & $\begin{array}{l}\text { Convenient } \\
\text { Easy to transport and } \\
\text { store } \\
\text { Has no substitute to use } \\
\text { for transportation }\end{array}$ & $\begin{array}{l}\text { Causes } \mathrm{CO}_{2} \text { emission } \\
\text { Changeable prices } \\
\text { Concentration of } \\
\text { supplies } \\
\text { Susceptible to political } \\
\text { instability } \\
\text { Transportation risk }\end{array}$ \\
\hline Gas & $\begin{array}{c}\text { Cost-effective and } \\
\text { convenient } \\
\text { Varied utilisation (e.g., } \\
\text { heating houses) }\end{array}$ & $\begin{array}{l}\text { Causes } \mathrm{CO}_{2} \text { emission } \\
\text { Expensive and risky to } \\
\text { transport and store } \\
\text { Requires appropriate } \\
\text { infrastructure } \\
\text { Susceptible to price } \\
\text { fluctuation } \\
\text { Concentration of } \\
\text { supplies }\end{array}$ \\
\hline $\begin{array}{l}\text { Nuclear } \\
\text { energy }\end{array}$ & $\begin{array}{c}\text { Does not cause any } \\
\text { emission } \\
\text { Limited source }\end{array}$ & $\begin{array}{c}\text { Public acceptance } \\
\text { Problems with waste } \\
\text { storage } \\
\text { High capital absorption } \\
\text { - can be uneconomic in } \\
\text { some markets }\end{array}$ \\
\hline Renewable & $\begin{array}{c}\text { Low emission based on } \\
\text { life cycle } \\
\text { Sustainable }\end{array}$ & $\begin{array}{c}\text { In general, costs are still } \\
\text { too high } \\
\text { Unsteady supplies } \\
\text { Development takes } \\
\text { some time } \\
\text { Localisation problems }\end{array}$ \\
\hline
\end{tabular}

variety of regulations that aim at reducing waste and making the public aware of the importance of waste segregation. That is why, numerous trainings are conducted for both children and adults in majority of the UN countries [Pawul, Sobczyk 2011].

Another serious global problem is, undoubtedly, air pollution that mostly results from industrial development. Producing, exploiting, and processing energy carriers, such as coal, oil, gas, and so on, has both positive and negative aspects (Tab. 1).

At present, special technologies for burning coal are applied to reduce the emission of harmful substances into the environment, such as: pulverised coal combustion, fluidised bed combustion, 
combined-cycle combustion utilising gas turbines, super-critical technologies, and ultra-super-critical technologies. They help to modify the process of combustion and re-use waste. Moreover, various methods are applied to remove dust and sulphur dioxide from exhaust gases or to reduce the emission of nitrogen oxides. At present, a number of countries worldwide focus on the environmental protection. Applying modern technology makes

\section{REFERENCES}

BEDNAREK-GEJO A., MIANOWANY M., SKOCZYLAS P., GŁOWACKA A. 2012. Świadomość ekologiczna studentów. Hygeia Public Health 47, 2: 201-206.

BEŁCH K. 2010. Kwestia ekologiczna w nauczaniu Jana Pawła II. Pedagogika Katolicka 6, 1: 83-94.

BOŁTROMIUK A. 2010. Polskie społeczeństwo wobec idei i zasad zrównoważonego rozwoju. Problemy ekorozwoju 5, 2 : 107-116.

DOŁĘGA J. 2006. Ekofilozofia - nauka XXI wieku. Problemy ekorozwoju 1, 1: 17-22.

DROBOT M. 2012. Świadomość ekologiczna mieszkańców Tarnowa. Praca magisterska pod kierunkiem dr Anny Gaweł, Uniwersytet Jagielloński, Kraków : 6-10; 39-43.

GAWOR L. 2006. Wizja nowej wspólnoty ludzkiej w idei zrównoważonego rozwoju. Problemy ekorozwoju 1, 2: 59-66.

HŁOB।Ł A. 2010. Teoria i praktyka edukacji ekologicznej na rzecz zrównoważonego rozwoju. Problemy ekorozwoju 5, 2: 87-94.

HULL Z. 2016. Ekofilozofia i środowisko przyrodnicze. Diametros 9: 105-115

JAN PAWEŁ II. 2001 Chrońmy rodzinę opartą na małżeństwie. Do rodzin przybyłych z całych Włoch, 20.10.2001 r.

JAN PAWEŁ II. 1991. Encyklika Centesimus Annus. Rzym 1.05.1991 r., rozdział IV.

JAN PAWEŁ II. 1995. Encyklika Evangelium Vitae. Rzym 25.03.1995 r., rozdział II.

JAN PAWEŁ II. 1979. Encyklika Redemptor Hominis. Rzym 4.03.1979 r., rozdział III.

JAN PAWEŁ II. 1979. Homilia w czasie Mszy św. Nowy Targ, 8.06.1979 r.

JAN PAWEŁ II. 1993. Nowe przymierze między kościołem a kulturą. Przemówienie do przedstawicieli świata nauki i kultury. Wilno 05.09.1993 r.

JAN PAWEŁ II. 2001. Przyszłość ludzkości idzie poprzez rodzinę. Do wykładowców i studentów Papieskiego Instytutu Studiów nad Małżeństwem i Rodziną. 31.05.2001 r.

JAN PAWEŁ II. 2000. Technika i przyroda: dwa wyzwania dla turystyki na progu XXI stulecia. Orędzie na Światowy Dzień Turystyki. 27.09.2000 r. (signed 29.07.2000 r.)

JAN PAWE II. 2001. Trzeba zapobiec katastrofie ekologicznej. Audiencja generalna. 17.01.2001 r.

JAN PAWEŁ II. 1999. Zrównoważony rozwój. Przemówienie do członków Papieskiej Akademii Nauk. 12.03.1999 r.

JAROMIN S.2012. Koncepcja ekologii ludzkiej według Jana Pawła II. Kwartalnik naukowy Fides et ratio 2, 10: 5-11. it possible to reduce the emission of harmful gases into the surroundings as well as to recycle a vast amount of waste. Additionally, all over the world, much attention is drawn to the question of educating the public in the field of the environmental protection [Lorenz 2005].

It is worth making the whole Polish society aware and appreciative of the natural resources as a value.

KLIMCZYK-BRYK M. 2000. Świadomość ekologiczna konsumentów i jej uwarunkowania. Zeszyty Naukowe Akademii Ekonomicznej w Krakowie 543: 95-103.

LORENZ U. 2005. Skutki spalania węgla kamiennego dla środowiska przyrodniczego i możliwości ich ograniczania. Mat. Szkoły Eksploatacji Podziemnej. Sympozja i Konferencje nr 64, Wyd. Instytutu GSMiE PAN, Kraków: 97-112.

MARTINO R. R. 2002. Dobro osoby ludzkiej jest najważniejsze, Wystąpienie podczas Światowego Szczytu w Johannesburgu poświęconego Zrównoważonemu Rozwojowi, 2.09.2002.

PAPUZIŃSKI A. 2006. Świadomość ekologiczna w świetle teorii i praktyki (Zarys politologicznego modelu świadomości ekologicznej). Problemy Ekorozwoju 1, 1: 33-44.

PAWUL M., SOBCZYK W. 2011. Edukacja ekologiczna w zakresie gospodarki odpadami jako narzędzie realizacji zrównoważonego rozwoju. Problemy ekorozwoju 6, 1: 147156.

TUSZYŃSKA L. 2006. Edukacja ekologiczna dla nauczycieli i studentów. Wyższa Szkoła Pedagogiczna TWP w Warszawie, Warszawa.

TUSZYŃSKA L. 2008. Diagnoza stanu edukacji środowiskowej społeczności lokalnych w wybranych regionach Polski, Wydawnictwa Uniwersytetu Warszawskiego, Warszawa.

TYBURSKI W. 2006. Powstanie i rozwój filozofii ekologicznej. Problemy ekorozwoju 1, 1: 7-15.

WSPÓLNADEKLARACJAPAPIEŻAJANAPAWŁAIIIPATRIARCHY BART七OMIEJA I. 2002. O obowiązku szanowania świata stworzonego, Rzym-Wenecja, 10.06.2002 r.

WÓJTOWICZ B. 2010a. Geografia Rozwój Zrównoważony Edukacja Ekologiczna. Prace Monograficzne 575, Wydawnictwo Naukowe UP, Kraków pp. 254,

WÓJTOWICZ B. 2010b. Poziom świadomości studentów oraz ich postawy wobec środowiska przyrodniczego, Rocznik Świętokrzyski. Ser. B - Nauki Przyrodnicze: 111-121.

WÓJTOWICZ B., ŻEBER- DZIKOWSKA I. 2006. Ecological awareness of students from the post primary system of education in Poland, St. Petersburg, Russia: 199-205.

WÓJTOWICZ B., ŻEBER-DZIKOWSKA I. 2011. The EcoEducation of the Youth in Gymnasiums and High Schools in Poland. In: Geology Geoecology and Evolutionary Geography ed. Nesterow E. M. Wyd. Orgkomitet MS GGEG RGPU im. A.I. Gercen, Sankt-Petresburg, Russia 11: 317-323. 